\title{
THE ROLE OF LAW ENFORCEMENT AND PUBLIC SAFETY FORCES FACING BIOLOGICAL THREAT
}

\author{
Iulian-Constantin MANAILESCU, \\ Ph.D. Candidate, Public Order and National Security, \\ „Alexandru Ioan Cuza” Police Academy, Bucharest, Romania \\ E-mail: driulianmanailescu@yahoo.com
}

\begin{abstract}
The COVID-19 pandemic has shown that both state structures and citizens have not been prepared to face up a biological threat. The hesitant way in which, at first, action was taken to limit the spread of the new virus led to the emergence of situations that changed the relationship between the state and the population. The trust of a part of the citizens in the state structures has been altered, especially because of the restrictions imposed to limit the spread of the virus. Those who are in direct contact with citizens and who apply these restrictions are the law enforcement and other forces protecting public order and safety. At present, the countries of the world are in a position to think over some strategy meant to restore the confidence of their population in these forces. This distrust, along with conspiracy theories, endangers national and regional security because it is the ground for the proliferation of populism and extremism. The paper presents the sticking points of the relationship between the citizen and the law enforcement and public safety forces that a strategy at the state and regional level should solve in order to restore a level of trust at which security is ensured.
\end{abstract}

Keywords: law enforcement; public safety; biological threat; trust; strategy.

\section{Introduction}

Pandemics are primarily outbreaks of infectious diseases that are transmitted from one human being to another and spread around the world. Beyond the debilitating, sometimes fatal consequences for those affected, they have negative social, economic and political consequences. They tend to be more problematic when the pandemic is due to a new pathogen, the mortality and hospitalization rate is high and spreads rapidly. According to Lee Jong-Wook, former director-general of the World Health Organization (WHO), pandemics do not respect borders. (World Health Organization, 2005) They can therefore simultaneously threaten societies, political systems and economies.

In the 1990s, more attention than ever was paid to pandemics and the threat to national security. In 1995 the World Health Assembly (WHA) agreed to revise the International Health Regulation (IHR), the only international legal framework governing how the WHO and its member states respond to outbreaks of infectious diseases, on the grounds that a review was needed to take into account "the threat posed by the international spread of new and recurring diseases." (World Health Organization 1995, 8)

In 2005 IHR revisions were adopted as AMS Resolution 58.34. Article 2 provides that the object and scope of the Instrument is the prevention, protection, control and response to the international spread of diseases through proportionate public health actions with the risks they pose to public health." (World Health Organization 2005, 7) Since its enforcement in 2007, the signatory states have worked individually and together to develop their basic capacities within the new framework. 
In the Report on the Safety and Security of Humanitarian Personnel and the Protection of United Nations Personnel, UN Secretary-General António Guterres stated that: "Global security has entered a phase of increasing and widespread disruption, characterised by an increased risk of civil unrest and a steady increase in instability around the world." (United Nations, 30 Octobre 2020). If we are to look at what is happening in many countries of the world, his apprehension has come true If, from an economic point of view, the situation seems to have a solution, in terms of security, the problems persist, especially in terms of citizens' trust in state institutions. The defeat of Donald Trump in the US presidential election last November and the relative inability of populists to make their voices heard on the health issue seem to testify to a new political cycle less promising for parties such as the National Rally (RN) in France, the Alternative für Deutschland (AfD) in Germany or the Lega in Italy.

In general, when beeing in opposition, right-wing populist forces struggle to occupy space, such as the German AFD, the Austrian Freedom Party (FPÖ) or the Batavi populists. In France, the RN does not seem to really benefit from the health crisis. If polls on voting intentions anticipate new records for Marine Le Pen, they must be read with the utmost caution, as the 2022 presidential term remains relatively distant and the electoral offer very uncertain (Cautrès, 2021). In Germany, these forces, following the September elections lost a significant number of seats this year.

In some European countries, populist formations already seem able to capitalize on concerns related to the health context, such as the recent appearance of Chega in Portugal or the Alliance for The Unity of Romanians (AUR) in Romania.

At the heart of the speeches of these formations are conspiracy theories about the COVID-19 pandemic. Mainly, they assert that the state, or the powerful states of the world, are in fact dictators who are using a disease that does not exist, in order to limit the freedoms of citizens. All measures taken to eliminate the pandemic: physical distancing, mask wearing or vaccination are considered measures to eliminate part of the population or turn citizens into slaves. Manifestations of physical disobedience are also encouraged, even those involving violence.

It is the law enforcement and public safety forces that are in direct contact with citizens in the application of the regulations governing restrictions. There are also those who must ensure the conduct of public events within the limits of the law. The policeman, regardless of state, is the one who imposes fines, for example. The anger of those who are followers of populist or conspiracy theories have a concrete person to show their anger at. Even if they are not followers of populists, some citizens end up feelings adverse towards law enforcement victimizing those who break the law and who are subject to tougher measures, especially in case of public meetings (the use of water cannons, for example).

Public order and national security are essential military and non-military capabilities of national security. An essential condition for them to remain of a standard that ensures a life democratic, it is necessary for citizens to have confidence in this type of authority. Such trust reduces the risk of accepting all sorts of populist, extremist and anarchist theories. If anti-state propaganda is prolific, present in all social networks, circulated by some media institutions, and this is not since the advent of the pandemic, the promotion of the role of law enforcement and public safety forces has been neglected in most of the countries of the world. In Romania, the situation is more dramatic, in schools the role of the policeman has been almost excluded from education. The new generations have refutations, rather, about the negative parts of the police, presented in the media, and nothing about how they should relate to this authority. Campaigns to explain how a democratic state works seem to be increasingly necessary.

If Sars COV-2 has found more types of vaccines, the treatments are increasingly yielding, the biological danger is that of non-compliance with restrictions amid the refusal to vaccinate. The forces of public order and safety, against a high background of distrust, are in a 
STRATEGIES XXI International Scientific Conference

The Complex and Dynamic Nature of the Security Environment

situation never seen before. In the application of laws concerning the pandemic, the opposition comes, and is often organized by representatives of the legislative or judicial power. Specifically, they are not in a position to deal with violent manifestations of those who do not accept the restrictions, but they are encouraged by parliamentarians or, in some states, by members of governments, but their work ends up being destabilised by some court decisions. Thus, their role in a safe society comes to be equated with that of representatives of forces that seek to harm the fundamental rights and freedoms of people. This article emphasizes, in particular, what has happened in Romania since the establishment of the state of emergency in the context of the pandemic. Any risk to the national security of this country poses a risk to European security. Without the application of a strategy to combat any biological threat, in which the main factor is held, in direct contact with the population of a country, the forces of public order and safety, the biological agent, regardless of its nature, or what it is sick, human or animal, spreads uncontrollably, affecting, as I said, security in all its dimensions. eventually destroying the democratic essence of a state.

\section{Police response during the COVID-19 pandemic}

Police services around the world are facing unprecedented challenges due to the COVID-19 pandemic. These challenges are related to the complexity and scale of the activities that the police are called to carry out and the changing nature of the role of the police during the pandemic. Although health workers are at the forefront, the police should be involved at every stage and the main interface with the population to answer citizens' questions and respond to their requests. Police services are overwhelmed by additional missions due to urgency: apps in public health orders, including quarantine or travel restrictions; securing health facilities, controlling the movements of large groups of people, helping to manage mass deaths, the protection of national stocks of vaccines or other medicines and the mission of informing the public and communicating risks. Coordinating the response is not spontaneous, as the police may have previously worked with most of the agencies through which the pandemic response plan is coordinated, including public health; medical workers and other basic bodies, such as telecommunications, electricity and water entities. In addition, the use of the military to enforce the application of emergency measures in many countries poses additional inssues in the relationship between the police and the Army Force becouse of some gaps in areas of competence and responsibility.

In the case of emergency situations, or those involving a security threat, the role of the police is well defined. The same is not the case with a pandemic because, in addition, complex situations arise that do not allow the definition of precise police roles in managing the situation.

Generally speaking, it is mentioned that more than the usual functions, the police have a Role in supporting the fight against the disease of and protect people from contamination.

The role of the police is also evolving to the extent that the context of the pandemic is changing and the needs of the population and the government are evolving. For example, courts may prioritise certain cases over others, depending on the situation, which will affect police decisions on crimes, prosecution and other cases for investigation.

Police staff requirements and organizational capabilities may also change during the pandemic, as they and their families may be affected by the deasese it self, at least in the same proportion as the rest of the population.

It is therefore extremely important to plan the police response to COVID-19 to deal with the evolving issues of preparedness, intervention and recovery after the pandemic. The importance of planning also lies in the reputational risks that the police may face during the 
response to the pandemic, knowing that the measures taken today would have an impact on the future relationship between the police and the population after the biological crisis.

\section{Trust in police influenced by the pandemic}

\subsection{France}

In the case of France, trust in the police, as measured annually by the CEVIPOF Trust Barometer, fluctuated between 63\% and 69\% between 2009 and 2014. In 2015, attacks against the satirical newspaper Charlie Hebdo and Hyper Cacher were at the origin of an 11-point return of confidence, bringing this rate to the unprecedented level of $80 \%$. However, within six years, French confidence in the police fell by 11 points, until the total cancellation of the capital acquired during the 2015 attacks. This erosion of the increased trust granted by the French during the attacks seems strange in the case of the police while the army, credited with a trust rating of $83 \%$ in February 2015 (a 7-point rebound from December 2014), benefited with a trust rating of $77 \%$ in February 2021. (Farde and Labarussiat 2021, 3)

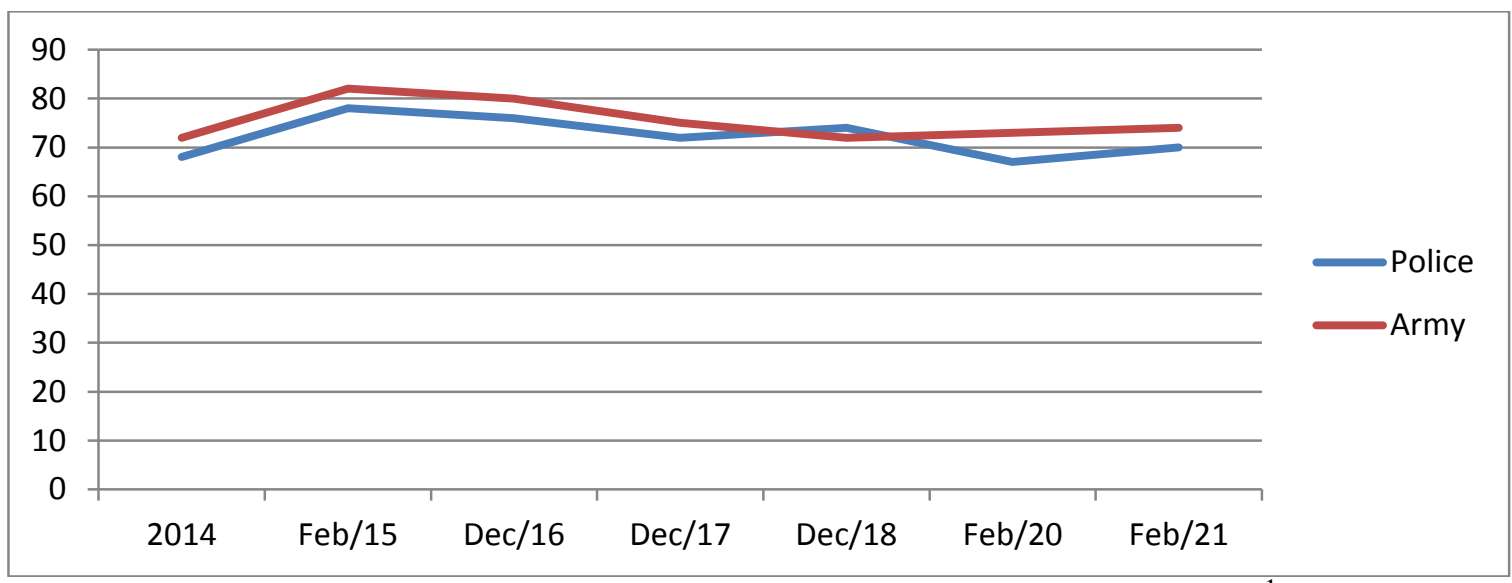

Figure no. 1: Evolution of trust in the police and the military ${ }^{1}$

However, in France, in 2020, the year when most restrictions were imposed, trust in the police had a slight climb. In 2020, due to restrictions, the number of demonstrations declined and police-demonstrators clashes were fewer. If in the case of the terrorist attack on Charlie Hebdo, the intervention of the police was considered beneficial, in 2020 and the first month of 2021, the police intervention in the case of the pandemic did not have the same good perception. As there were no large-scale confrontations like those in 2018, 2019, in which the ,yellow vests" almost started a war with law enforcement, forces the citizens' dissatisfaction did not spill over to the police.

\subsection{Federal Republic of Germany}

Most Germans trust doctors, the police, universities and the Federal Constitutional Court. This is the result of a survey published in Cologne by the Forsa Institute for rtl/nTV trend barometer. „Four-fifths of citizens each trust the police and the Federal Constitutional Court (78 percent)". (Forsa poll: Doctors and police enjoy great confidence 2021)

More than 4,000 citizens were surveyed at the beginning of the year. A year earlier, most socially relevant institutions had performed worse. In May - during the coronavirus pandemic - trust returned to most institutions and has remained at a high level since then.

\footnotetext{
${ }^{1}$ Source: Data obtained from the survey Le décrochage des 18-24 ans, Note de recherche Le Baromètre de la confiance politique / Vague 12, March 2021,
} 
STRATEGIES XXI International Scientific Conference

The Complex and Dynamic Nature of the Security Environment

In the case of Germany, in addition to the existence of a consolidated democracy, the state institutions had a good communication with the citizens and explained each of the regulations established at federal level and in each land, with how to apply them and the duties of each authority involved.

\subsection{Romania}

As far as Romania is concerned, the General Police Inspectorate, in collaboration with the National Institute of Statistics, conducted the study „Public Safety Survey" for several years, respectively 2015, 2016 and 2017. The investigation also concerned the trust in the police as a governmental institution, and the measured indicator was the degree of trust in the police and other institutions on duty in the sphere of public safetyand the question applied was: How much trust do you have in ...? (Ancheta siguranței publice 2015, 2016, 2017).

Table no. 1: Trust in institutions ${ }^{2}$

\begin{tabular}{|l|l|l|l|}
\hline \multicolumn{2}{|c|}{$\mathbf{2 0 1 5}$} & $\mathbf{2 0 1 6}$ & $\mathbf{2 0 1 7}$ \\
\hline Gendarmerie & $71,3 \%$ & $75,3 \%$ & $77,1 \%$ \\
\hline Police & $68,3 \%$ & $72,1 \%$ & $75,1 \%$ \\
\hline Border police & $65 \%$ & $69,3 \%$ & $71,7 \%$ \\
\hline Local police & $64,7 \%$ & $66,7 \%$ & $68,1 \%$ \\
\hline
\end{tabular}

As seen in the table above, the trust in the police was in a continuous climb. Trust has been steadily growing for all law enforcement and public safety institutions.

The same studies have established the degree of satisfaction of the citizens, during the same period, in the work of the police.

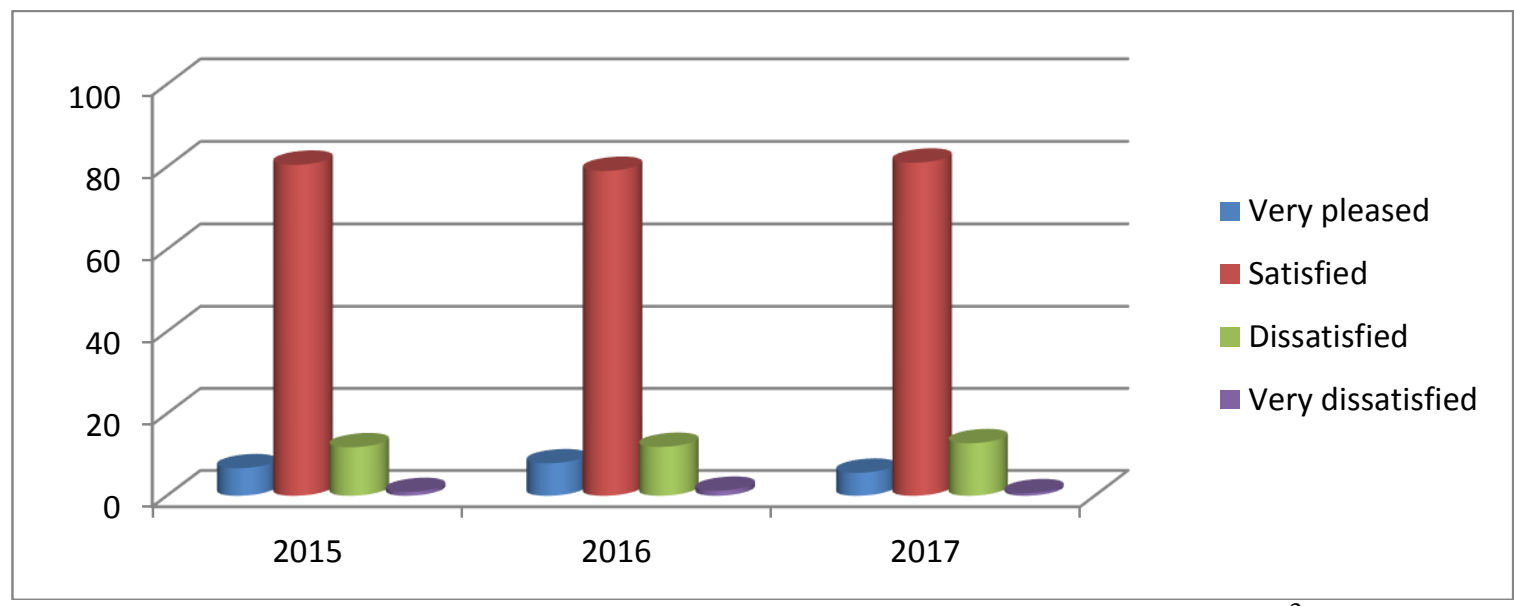

Figure no. 2: Degree of satisfaction with the work of the Police ${ }^{3}$

Even though the trust in the institutions of public order and safety has increased, the degree of satisfaction with the work of these institutions has remained approximately constant. To the satisfied answer, the variation was about one percent.

As has been observed during the COVID-19 pandemic, the authority of the police has played an important role, and as will be seen in the article, this authority may be questioned.

\footnotetext{
${ }^{2}$ A.N.: Data obtained from Ancheta siguranței publice, 2015, Ancheta siguranței publice, 2016, Ancheta siguranței publice, 2017.

${ }^{3}$ A.N.: Data obtained from Ancheta siguranței publice, 2015, Ancheta siguranței publice, 2017, Ancheta siguranţei publice, 2017.
} 
What's interesting is what level of trust this trust was at during the pandemic years. Unfortunately, the only relevant studies exist since 2015, 2016 and 2017.

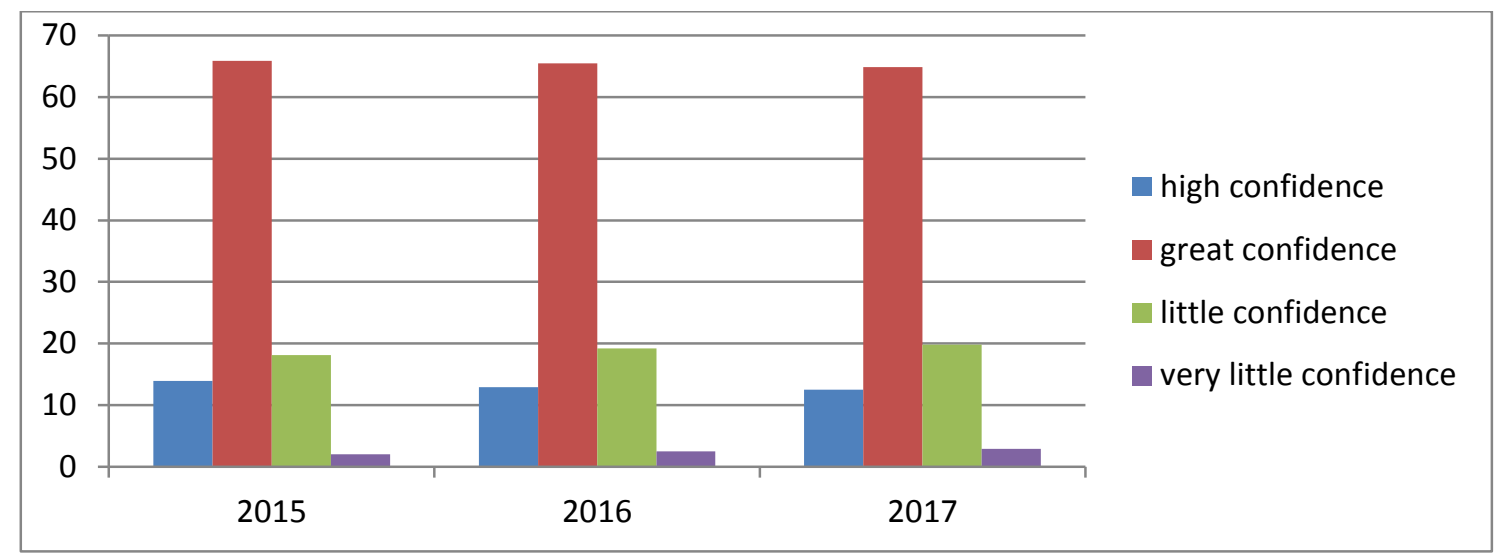

Figure no. 3: Degree of trust in the authority of police officers ${ }^{4}$

As seen in the chart above, the trust in the authority of the police was at a high and steady degree.

For the period before the pandemic, the study ,Top trust in domestic and international institutions. The Army, the Church and the Gendarmerie on the first places / NATO and the European Parliament in terms of external institutions" ", carried out at the command of the Konrad Adenauer Foundation between 5 and 13 March 2019, showed a constant trust in the institutions that ensure national security. (G 4 Media.ro 2019)

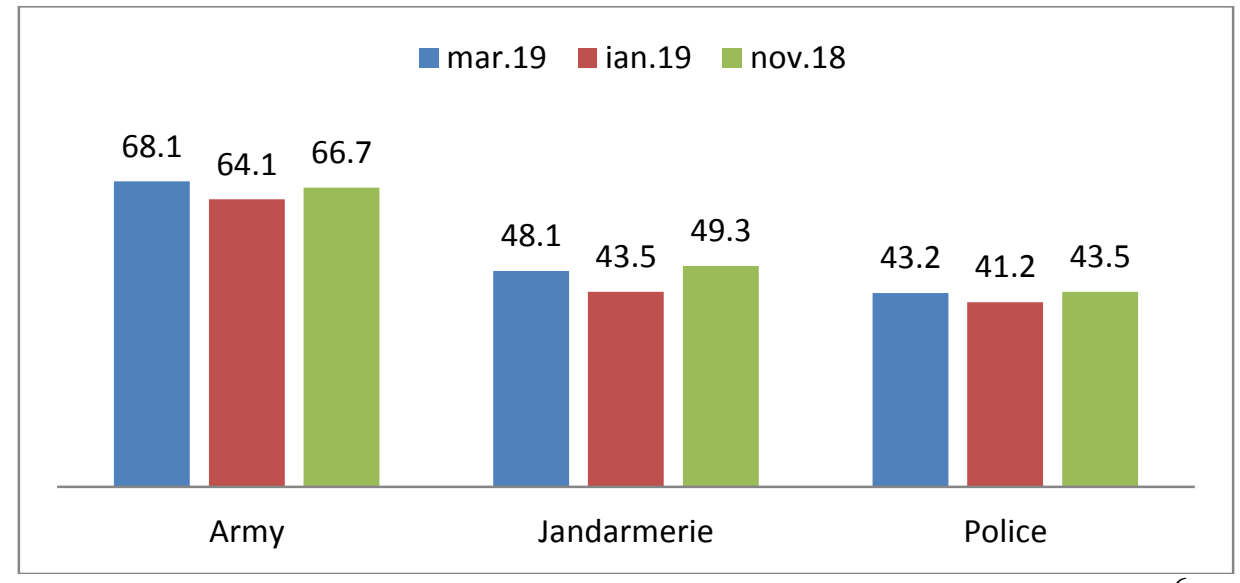

Figure no. 4: Trust in national security authorities and institutions ${ }^{6}$

Of all the national security authorities, the police recorded the lowest degree of trust.

In March, 2020, when in Romania by presidential decree it entered into a state of emergency. The legislation provided for the restriction of certain rights and freedoms, such as:

a) free movement;

b) the right to intimate, family and private life;

\footnotetext{
${ }^{4}$ Data obtained from Ancheta siguranței publice, 2015, Ancheta siguranței publice, 2017, Ancheta siguranței publice, 2017.

${ }^{5}$ Article 2, DECREE No. 195 of March 16, 2020 on the establishment of the state of emergency on the territory of Romania, published in the Official Gazette no. no. 212 of 16 March 2020

${ }^{6}$ Data obtained from the INSCOP Survey: Top trust in domestic and international institutions. The Army, the Church and the Gendarmerie on the first places / NATO and the European Parliament in terms of external institutions, March 22, 2019.
} 
c) inviolability of the home;

d) the right to learn;

e) (e) freedom of assembly;

f) the right to private property;

g) the right to strike;

h) economic freedom. ${ }^{7}$

As will be seen in the following examples, these restrictions were met with violent manifestations towards the police, the first authority with responsibility for compliance with the norm.

The survey conducted by INSCOP: „How much confidence do Romanians have in the professions most exposed to risks in the context of the spread of the coronavirus epidemic" showed what was the level of trust in the police in March 2020. (INSCOP 2020).

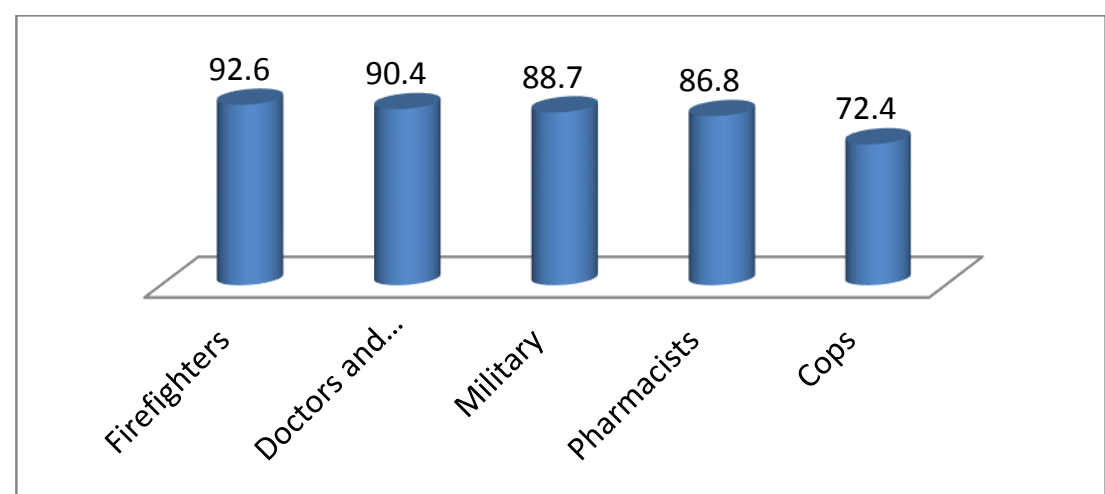

Figure no. 5: Romanians' trust in professions at risk during the pandemic ${ }^{8}$

As seen in the graph above, the police showed the lowest degree of trust, which announced the existence of a problem with the policeman-citizen relationship.

Three months later, the Romanian Institute for Evaluation and Strategy - IRES conducted the study: "2020 - Elections in pandemic" which evaluated the citizens' trust in the state institutions. (Sondaj realizat în iulie 2020)

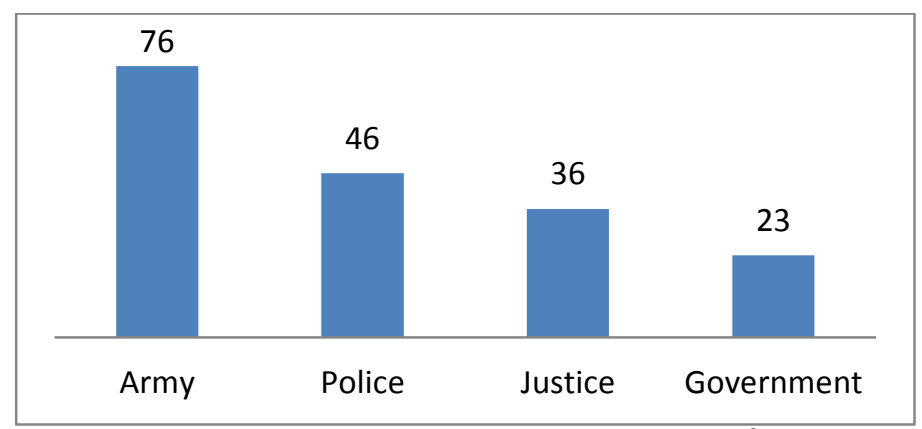

Figure no. 6: Trust in institutions ${ }^{9}$

The results are relevant because they provide a differentiation of trust in the police from trust in the military. In March 2020 this difference stood at about 16 percent, in just three

\footnotetext{
${ }^{7}$ A.N.: Article 2, DECREE no. 195 of March 16, 2020 regarding the establishment of the state of emergency on the Romanian territory, published in the Official Gazette no. 212 of 16 March 2020.

${ }^{8}$ A.N.: Data obtained from the INSCOP survey:"How much confidence do Romanians have in the professions most exposed to risks in the context of the spread of the coronavirus epidemic", march 2020.

${ }^{9}$ A.N.: Data obtained from the IRES survey: „2020 - Elections in pandemic”, July 2020.
} 
months, in June of the same year, the percentage climbed to $30 \%$. This shows that the imposition of restrictions has led to a decrease in trust in the police.

The reluctance towards the measures imposed by the state of emergency, especially those that referred to the limitation of the right of movement, was manifested by aggression towards the policemen. Thus, in April 2020, in Rahova several people who organized a party with music in the middle of the street, threw stones and various objects at the policemen who arrived at the scene to restore public order and safety. Not only was the authority conferred by the status of a policeman not taken into account, but it required the intervention of other law enforcement who had to resort to gunfire. (DIGI 24 2020) This type of incident has been repeated in several places in the country, such as Galați.

Throughout the state of emergency and the alert period, there were verbal altercations between citizens and policemen regarding the wearing of a mask.

The authority of the policemen and the trust in them is questioned by the entry into the Romanian Parliament of the first anti-system and populist party, the Alliance for the Unity of the Romanians (AUR). The speech of the new lawmakers is calling into question the very essence of the work of the policemen in the pandemic. The state becomes, according to the propaganda made by this party, the enemy of the people who, through the restrictions imposed, want to turn the citizens into slaves, and even kill them by vaccination.

The support of all sorts of conspiracy theories from the parliament rostrum, the attacks, often furious at state institutions and authorities, turn the policeman from a defender of the law into a criminal. Not only is his authority thus eliminated, but his very physical integrity is endangered. When the one who has to restore public order and safety loses his authority, in the midst of the hybrid information war, national security is put at risk. In such a situation, security is attacked frontally from at least two sides.

\section{Conclusions}

In the situation of the COVID-19 pandemic, security is under attack from at least two sides. First of all, the attack is directed at national health, the non-observance of restrictions, the small number of vaccinated people end up bringing to its knees the health system that, nowhere in the world has been built to cope with such a large number of sick people as SarsCOV2 does. Second, public order and national security are under attack. The implications of the pandemic lead to a state of tension and revolt among citizens, whose rights and freedoms are restricted. The serious thing is that this attack can no longer be effectively countered by law enforcement and public safety forces, because the degree of trust in their work and authority decreases. However, as we have seen in the case of Germany, this kind of trust has remained high despite the pandemic. In addition to the history and socio-psychological typology of the citizens of this country, behind this trust lies a strategy, over several years, of how the state promotes and explains its actions. The role and duties of police officers are well understood by the average citizen.

France has the peculiarity, against the background of left-wing ideologies, of having, frequently, demonstrations and strikes. In the case of the "yellow vests" we can say that the actions of the state authorities and institutions have not been sufficiently well explained and that, although the demonstrators destroy and manifest themselves violently, the response with the same measure of the authorities is reinterpreted as dictatorial actions on the part of the state. Populist, anti-system political forces are also there against the measures taken to combat the COVID-19 pandemic, but their share will be about after next year's elections. In the June 2021 regional elections, the National Assembly, the far-right party of France's Marine Le Pen, failed to win in any region. 
STRATEGIES XXI International Scientific Conference

The Complex and Dynamic Nature of the Security Environment

In Romania, at least in the case of the Police as a public order and safety authority, confidence in its activity and authority is decreasing. AUR, a political party that opposes the measures to combat the pandemic and which is against the current state structure, according to the latest polls is active both in the parliament's rostrum, but also in the public, physical and online environment, with messages of physical, antivaccine disobedience. In this situation, it is all the more necessary to carry out studies by identifying citizens' dissatisfaction and expectations towards police officers, establishing key points for a promotion of their activity and restoring the level of trust.

Restoring the citizen's trust in law enforcement and public safety involves a state-wide strategy. At EU level, the general framework of this strategy must be established: the causes that lead to the weakening of trust, the actors that can bring about this trust. Each state, the EU member would have to set its own strategy. A main point of this strategy, at the level of the general framework, is necessary to: the regulation as clear and appropriate as possible to the situations possible, in the normative, by each Member State of all the actions of the police officers involving, any type of citizen-police relationship.

We have stated in the above lines that the role of the police in the event of a pandemic is far from defined. But, in the last almost 2 years, they have outlined the role of law enforcement and public safety forces in real pandemic situations. The pandemic started in 2020 has created the possibility of including in national security strategies the definition of the role of the police, in the event of a biological threat.

\section{BIBLIOGRAPHY:}

***, Article 2, DECREE no. 195 of March 16, 2020 regarding the establishment of the state of emergency on the Romanian territory, published in the Official Gazette no. 212 of 16 March 2020.

***, DIGI 24. 2020. "Bătaie cu pietre în plină stradă, în București. Polițiștii au tras și focuri de armă. 37 de persoane duse la audieri." 19.04.2020, URL: https://www.digi24.ro/ stiri/actualitate/bataie-cu-pietre-in-plina-strada-in-bucuresti-politistii-au-tras-si-focuride-arma-1294508

***, DIGI 24,2021. "Partidele lui Macron și Le Pen suferă înfrângeri categorice la alegerile regionale din Franța. Record de absenteism.” 27.06.2021, URL: https:/www.digi24. ro/stiri/externe/partidele-lui-macron-si-le-pen-sufera-infrangeri-categorice-la-aleg

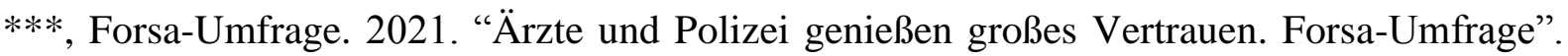
Evanghelisch.de, 11.01.2021, URL: https://www.evangelisch.de/inhalte/181070/11-012021/forsa-umfrage-aerzte-und-polizei-geniessen-grosses-vertrauen

***, Fundația Viață și Lumină, Asociația Centrul pentru Inovare Publică, Institutul Român pentru Evaluare și Strategie - IRES. 2020. "2020-Alegeri în pandemie”, sondaj, Institutul Român pentru Evaluare și Strategie, 2020.

***, G4 Media.ro. 2019. “Topul încrederii în instituții interne și internaţionale. Armata, Biserica și Jandarmeria pe primele locuri/ NATO și Parlamentul European la capitolul instituţii externe.” G4 Media.ro, 22 march 2019: https://www.g4media.ro/sond

***, INSCOP Research. 2020. "Câtă încredere au românii în profesiile cele mai expuse riscurilor în contextul răspândirii epidemiei de coronavirus" URL: https://www.inscop.ro/graficul-saptamanii-cata-incredere-au-romanii-in-profesiile-celemai-expuse-riscurilor-in-contextul-raspandirii-epidemiei-de-coronavirus/ (sondaj INSCOP martie 2020) 
***, Institutul de Cercetare și Prevenire a Criminalității. 2016. "Ancheta siguranței publice, 2015", https://www.politiaromana.ro/files/pages_files/ancheta_sigurantei_publice_ 2015.pd, 2016.

***, Institutul de Cercetare și Prevenire a Criminalităţii. 2017. "Ancheta siguranței publice, 2017”. https://www.politiaromana.ro/files/pages_files/ancheta_sigurantei_publice_ 2016.pdf, 2018.

***, Institutul de Cercetare și Prevenire a Criminalității. 2018. "Ancheta siguranței publice, 2017". https://www.politiaromana.ro/files/pages_files/ancheta_sigurantei_publice_ 2017.pdf, 2018.

***, United Nations. 2020. "COVID-19 for global security: heightened instability and increased threats to United Nations staff, ORG/1711." URL: https://www.un.org/ press/en/2020/org1711.doc.htm

***, World Health Organization. 2005. "The World Health Assembly adopts new international health regulations: the new rules govern the national and international response to outbreaks". URL: https://apps.who.int/mediacentre/news/releases/2005/pr_wha03/ en/index.html

***, World Health Organization. 1995. "Review and Update of International Health Regulations", WHA48.7, World Health Assembly 48, URL: https://apps.who.int/ iris/bitstream/handle/10665/178296/WHA48_1995-REC-1_eng.pdf?sequence=1, 1995.

***, World Health Organization. 2005. "Review of International Health Regulations", WHA58.3, World Health Assembly 58. URL: https://www.who.int/ipcs/publications/ wha/ihr_resolution.pdf, 2005.

CAUTRÈS, Bruno. 2021. "La confiance des Français à l'épreuve de la crise." Institut Montaigne, 25 february 2021 URL: https://www.institutmontaigne.org/blog/laconfiance-des-francais-lepreuve-de-la-crise

FARDE, Guillaume and LABARUSSIAT, Floriane, 2021. "La confiance police-population en 2021: Le décrochage des 18-24 ans, Note de recherche Le Baromètre de la confiance politique". Vague, 12 march 2021: 1-11.

LABARUSSIAT, Guillaume and Floriane, FARDE. 2021. "La confiance police-population EN.” Sciense Pro, 2021: 1-10. 